\title{
Shortageflation 3.0: War economy - State socialism - Pandemic crisis
}

\author{
GRZEGORZ W. KOLODKO* (1)
}

Transformation, Integration and Globalization Economic Research (TIGER), Kozminski University, Jagiellońska 57, 03-301, Warsaw, Poland

Received: June 20,2021 • Revised manuscript received: August 1, 2021 • Accepted: August 15, 2021

(C) 2021 Akadémiai Kiadó, Budapest

\begin{abstract}
The crisis caused by the coronavirus pandemic has prompted governments and central banks to take unorthodox measures aimed at protecting the standard of living of people and sustaining the production and service activities of companies. The policy of aggressively increasing the supply of money has entailed a significant rise in the budget deficit and public debt. It is important to consider the extent of its impact on the escalation of inflation processes and to formulate suggestions regarding the economic policy. Inflation is already higher than the official indicators show it, because it is partly suppressed. The increase in the general price level does not fully reflect the actual inflation rate. We are dealing with shortageflation - the simultaneous occurrence of price inflation and repressed inflation accompanied by shortages. It is methodologically interesting to compare this current phenomenon, 3.0, with the suppression of inflation in the war economy, 1.0, and in the economies of state socialism, 2.0. Such comparisons highlight not only the similarities of these processes but also the differences resulting from the specificity of responses of households and businesses. This paper discusses five channels of unloading excessive savings, indicating the most beneficial ones from the point of view of sustainable economic development in the post-pandemic future. It is particularly important to prompt the conversion of compulsory savings into voluntary savings, and at the same time, to stimulate the transformation of the inflationary monetary reserves into the effective demand expanding the use of existing production capacities and investments creating new capacities.
\end{abstract}

\section{KEYWORDS}

open inflation, suppressed inflation, shortageflation, money supply, compulsory savings, pandemic, Poland

\section{JEL CLASSIFICATION INDICES}

C20, D14, E21, G40, P22, P51

* Corresponding author. E-mail: kolodko@kozminski.edu.pl 


\section{INTRODUCTION}

Are we going to face a significant acceleration of inflationary processes? While some fear this, or even predict the next cataclysm, others, on the contrary, compete to present minimalist forecasts of price increases. As is always the case when two different opinions are confronted, it is this time that first the subject of controversy needs to be properly identified, and then, economic categories that are at the heart of the debate need to be correctly defined. It sometimes happens those similar terms are used for various phenomena and processes, while at other times the same event and developments are called differently, which is the cause of many misunderstandings. This in turn may lead to erroneous reactions not only in the sphere of theoretical interpretations but also in economic policy.

When searching for answers to the possible evolution of the situation with regard to inflation in the context of the global pandemic, which is a humanitarian, but also social and economic disaster, it is necessary first to propose an appropriate taxonomy of inflation.

Although the syndrome of contemporary inflation is unique in history, it has some features similar to that through which states, societies and economies have already gone through. Therefore, it is also worth reaching to comparative analyses, as they can somehow suggest what to do and what to avoid.

\section{VARIOUS FACES OF INFLATION}

Inflation makes itself felt throughout the world, with few exceptions of deflation - the opposite process. Apart from the countries, such as Argentina and Turkey, where the consumer price index (CPI), in 2021 is the forecast by the Economist Intelligence Unit (EIU), to amount to approximately 43 and $12 \%$, respectively, inflation is kept under control at a low, practically harmless level for the economy. It is a creeping inflation. Naturally, there are exceptions with galloping inflation or even hyperinflation, such as the economically devastated Venezuela (CPI of December 2020 to December 2019 of 2,960\%) and Zimbabwe (350\%), respectively.

In an overwhelming majority of economies, the governments and central banks have issued record amounts of money in peacetime in response to the COVID crisis. So, if a lot of money has been "printed" without being covered in a real offer of goods, the question is why inflation did not accelerate? On the other hand, others believe that it is already substantially higher than just a few months ago: "The inevitable has begun. America's consumer-price index (CPI) in March was $2.6 \%$ higher than a year earlier, when prices collapsed as the pandemic struck. The increase in inflation from $1.7 \%$ in February was the biggest rise since 2009, the last time the economy was recovering from a deep shock. Several more months of high numbers - by richworld standards - are coming. The CPI could reach over 3.5\% by May" (Economist 2021b). What is important in this observation is the statement that it applies to the standards specific to the rich countries, and we should remember, that one-seventh of people living there have been producing almost half of the world's production for over a decade.

Well, inflation has already increased, except that we are dealing with inflation that is partly suppressed. Increased money supply has been, de facto, largely withdrawn from circulation in the sense that it has been frozen in the form of forced savings caused by the blocking parts of the 
economy in the battle against the pandemic. These economies are in a transitional state and eventually, these financial assets will make themselves felt through five channels:

1. An increase in the effective demand that will entail an increase in production and employment;

2. An increase in imports that will lead to an increased supply, but also to the deterioration of the balance of payments;

3. An increase in voluntary savings;

4. An increase in prices of commodities and assets, including shares and real estate, and

5. An inflationary increase in prices.

We do not know their proportions ex-ante, the less so because the problem is contextual. For example, the second channel is easier to be used by countries that have previously been characterised by the surplus of the balance of payments or substantial foreign exchange reserves. From this point of view, Germany and Russia, for example, are in a better situation, while the situation of the USA and Brazil is relatively worse. However, we know that in any case, it is worth to maximise the sizes of the first and third channel.

Let us add that, regardless of the exceptional nature of the pandemic, a long-term upward trend in the overall savings rate can be expected in many economies, especially if the rate was low, as was the case in the post-socialist European countries. The increased propensity to save, so to put aside a growing proportion of disposable income, is associated with uncertain prospects for the future, ageing of populations, and changes in the consumption patterns.

The classical economic theory understands inflation as an increase in the general price level. In the liberalised market economy, it can be caused by the growing costs pushing up prices (cost-push inflation) or by the flow of excessive demand pulling up prices (demand-pull inflation). In the economic reality, these two forms coincide, although unevenly. For households it does not really matter; prices are rising, so the costs of living are rising, and that is why we do not like inflation. And why the prices are raising is the question addressed to others - economists and politicians.

We do not like inflation because it is a rise in the general price level, where the average of this rise is a result of diversified changes in the prices of individual goods and services. Currently, this diversification due to supply and demand shocks caused by the aftermath of the pandemic is exceptionally high and, by the way, annoying. For example, in Poland, according to the official data from the Central Statistical Office (GUS), the general price level rose by little $-2.4 \%$, last year, December 2019 to December 2020, and 3.4\%, taking account of relations of annual averages. But these indicators hide such drastic differences as an increase in the prices of waste collection by as much as $51.1 \%$ or in the prices of fruits by $17.6 \%$, and a decrease in the prices of telecommunication equipment by $10.9 \%$ or clothing by $3 \%$. Such dispersion of the movement of prices of various ranges of goods, compared to the process of their growth that is more aligned with the average, results in a far greater extent of income redistribution which is economically unjustified, as it does not stem from changes in the workforce productivity.

It is also important to differentiate between nominal incomes, as their level determines the structure of expenditures, and therefore, the related severity of inflation. If, say, a family of five has a net income of PLN 10 thousand, then they spend more than a half from two thousand per capita on food. The prices of food increased in Poland by $5 \%$ on average (year on year), so by half more than the overall consumer price index is. When a family of three has PLN 40 thousand 
at their disposal, then they spend, say, PLN 10 thousand on food, thus they suffer relatively less due to the hike in the prices of bread by $8.1 \%$ or meat products by $9.5 \%$. Such differences in the dynamics of individual prices cause that inflation in the public perception is estimated to be at a much higher level than it actually is. We do not know exactly its real level, but the perceived inflation in several countries is certainly higher than the official indices show.

The pandemic has changed the structure of spending and consumption, and the things households are regularly buying became more expensive. Nevertheless, opposite trends can also be observed. In particular, the prices of digital services, whose share is increasing, have dropped (Reinsdorf 2020). Moreover, the officially calculated index of retail prices of goods and services acquired by households does not take into account the rising prices of real estate, especially housing. For instance, in Poland in 2020, housing became more expensive, on average, by $8.9 \%$, including on the primary market by $6 \%$ and secondary market almost twice as much - by $11.2 \%$. This is fully in line with the international standards, but the reasons of this go beyond the comprehension of the man of the street.

Yet people are not soulless analysts. They do not calculate averages and do not estimate the shares and weights, but easily succumb to fragmentary information from their own, not at all professional, observations, but also - alas - quite often misleading suggestions of media pundits. The psychological mechanism works like this: A person leaving a hairdresser says "everything is getting more expensive, by several \%!" (in Poland the prices of hairdressing and beauty services in 2020 increased on average by $11.1 \%$ ), but when leaving a gas station, the same person does not claim that "everything is getting cheaper, by more than $10 \%$ !" (fuel prices decreased by $10.7 \%)$. This subjective aspect is important as it strengthens the inflationary expectations. Since the public perception is that "everything is getting more expensive" on a large scale, then in the real world it may continue to get more expensive because prices adapt to some extent to expectations.

What is more, if the costs of living are going up, the employees require or even demand that it should be compensated, that is the wages and benefits should also be increased. Preferably in excess; not by as much as the prices grow according to the government, but by as much as they "really" grow. This type of wage revindication may prove to be more effective, the more it is accompanied by labour shortages in certain segments of the labour market. This may exacerbate inflationary pressure and - worse still - set off the spiral of wages (and hence, costs as well) and prices. It is therefore so important to take all necessary measures that would cool down the inflationary expectations.

\section{SUPPRESSING INFLATION}

The problem does not end here, by no means. If it did, handling inflation and keeping it under control would not be very complicated. Unfortunately, it is because again we are dealing not only with price inflation, also referred to as open inflation, but also with suppressed inflation, also referred to as hidden inflation. This second type is known from the past (Charlesworth 2003; Kolodko 1984). In the rich countries of the West, it took its toll during World War II. The administrative, politically imposed by governments, freezing of prices at a relatively low level that did not balance the supply and demand, was accompanied by forced savings, which financed military efforts. They took the form of financial resources unintended by people; they 
saved some of their disposable income not because they wanted to, but because they were forced to do so by the lack of consumer goods in free sale. In the US, nearly everything was rationed from coffee to shoes. Due to the conversion of industry to military production, it was forbidden to produce consumer goods such as bicycles or refrigerators. It is hard to believe that in 1943 only 139 passenger cars were sold (Economist 2021a).

When the war ended, despite the general recession, to which also the business cycle contributed, there was a boom in the consumer sectors of industries and services. It was caused by households which rushed in great numbers to the market with their previously forced savings. Five years after the war, there were more than 8 million cars produced. The way in which the US recovered from suppressed inflation was creative. They managed to avoid its escalation into a destructive galloping inflation, although in 1946 and 1947 it was substantial (Table 1).

It is worth recalling that after World War I, many countries experienced hyperinflation that was devastating to their economies (Lopez et al. 2018). After World War II, on both sides of the Atlantic (but by no means in all continental European countries, where for example, Hungary reported the highest inflation in the history; in mid-1946 the prices doubled every $15 \mathrm{~h}$, growing by more than $200 \%$ per day!), savings generated by the compulsory deferral of a part of unsatisfied demand were turned into an additional flow of demand, over that created by current income. This was a great boost to the economy, which rapidly increased the utilisation of the existing production capacities, co-financed investment expansion forming new capacities, and supported the conversion of part of the industry into peace-time production. Instead of providing tanks to the army, tractors were sold to farmers; instead of providing guns to soldiers, typewriters were sold to journalists; instead of transporting the army to Europe using ships, passenger ships began to carry tourists.

After those experiences - let us call them suppressed inflation 1.0 - apart from the shortlived and rather unsuccessful incidents of freezing prices and wages, the suppressed inflation was something unknown in the highly developed capitalist economies, whereas they often suffered from high price inflation, sometimes combined with rising unemployment and low production growth. This was the so-called stagflation (Blinder 1979), and in extreme cases, when the increase in prices was accompanied by a drop in production, slumpflation. The failure to cope with high inflation, when its index in 1979 was $13.3 \%$ in the US, and reached $18 \%$ a year later in the UK, was one of the causes that brought Ronald Reagan and Margaret Thatcher to power.

Table 1. Output growth and rate of inflation in USA and UK, 1946-1949 (\%)

\begin{tabular}{|l|c|c|c|c|c|}
\hline & Year & 1946 & 1947 & 1948 & 1949 \\
\hline \multirow{3}{*}{ USA } & GDP & -11.6 & -1.1 & 4.8 & -0.6 \\
\cline { 2 - 6 } & CPI & 18.1 & 8.8 & 3.0 & -2.1 \\
\hline \multirow{3}{*}{ UK } & GDP & -2.5 & -1.3 & 3.2 & 3.3 \\
\cline { 2 - 6 } & CPI & 3.1 & 7.0 & 7.7 & 2.8 \\
\hline
\end{tabular}

Sources: For US: US GDP 2021 and US Inflation 2021; for UK: Measuring Worth 2021 and Historical UK 2021. 
On the other hand, suppressed inflation, like cancer, was destroying the economy of state socialism (Kolodko 1986; Nuti 1986) ${ }^{1}$. We will denote it as 2.0. Naturally, its scale varied. It was described as inflationary phenomena, the issue of economic imbalance was discussed, and the changes in the price levels or hidden inflation were addressed (Howard 1976; Portes 1977; Steiner 1982). It was quite widely assumed that the real inflation rates were by 1-2 percentage points higher than the official data (Wiles 1982; Adirim 1983).

It is a fact that, to a certain extent, traditionally understood inflation was successfully concealed by suppressing price rises through political decisions - against the logic of the market economy, with which the centrally planned economy of that time had little in common - but this was akin to an ostrich burying its head in the sand. What the government and the official economy did not want to perceive was seen - or rather felt in the form of severe shortages of consumer goods - by every housewife and every purchasing officer in a state enterprise.

Later on, the complexity of inflation in the bureaucratic socialist economies was discussed much more. Undoubtedly, the works of János Kornai (1980, 1982, and 1986) were groundbreaking for academic discussions of this issue. In the 1980s, inflation made itself felt least sharply in the countries of orthodox state socialism, in the former Czechoslovakia and the German Democratic Republic, while it was felt most in the economies introducing timid market-oriented reforms, in Poland and Hungary, and especially in Yugoslavia characterised by a relatively high degree of decentralization of economic governance. Worse still, as a result of inconsistent reforms that liberalised trade only partially but did not introduce sufficiently hard budget constraints and systemic barriers for the creation of excessive demand impossible to be balanced by the supply-side capacity of the economy (including imports), the lack of goods was accompanied by the process of price growth. This syndrome is called shortageflation (Kolodko MacMahon 1987); although things were getting more and more expensive, they were not always buyable. It was its escalation, contributing to the deterioration of business efficiency and increasing annoyance of daily life of people, that was one of the main causes for the collapse of that economic system.

In contrast to the recovery from suppressed inflation 1.0 in the advanced capitalist countries, especially in the US and the UK (Hicks 1947), during the post-socialist system transformation, the recovery from the shortageflation 2.0 was disastrous (Kolodko 1991; Mundell 1995, 1996; Nuti 2018b). To a great extent, this was a consequence of succumbing to the pressures of neoliberal economic doctrine (Harvey 2005; Kolodko 2000), which unfortunately became popular and had a very costly effect on the economic policy and direction of reforms implemented in the countries of Central and Eastern Europe and the former Soviet republics (Nuti 1990; Rosati 1991; Podkaminer 1992). As a result, the so-called transformational recession lasted from three years in Poland to 10 years in Russia, where the GDP level fell by more than half.

In Poland, the decline in production took place from the second half of 1989 to the first half of 1992. According to the official data from the GUS, in 1990 and 1991 GDP shrank by 11.6 and $7.0 \%$, respectively. It should be noted that such macroeconomic data - estimated for such a turbulent period entangled in profound structural changes in production and prices - must be treated with due caution; in the case of Poland, though, they were positively verified by international organisations, including the International Monetary Fund. This has by no means

${ }^{1}$ Commemorating the untimely death of Mario Nuti see Estrin - Uvalic (Acta Oeconomica 2021, 2). 
stopped the apologists of the so-called shock therapy from various manipulations and attempts to reduce the depth of the recession (Winiecki 1991). Other authors, in turn, point out that the recession was even deeper, because according to later calculations by the GUS, in 1990-1991 the fall in GDP amounted to a total of almost 23\% (Jakubowicz 2020). In other words, after two years of the shortageflation 2.0 syndrome, national income was a fifth lower and prices almost 12 times higher! (Table 2).

In fact, in Poland, as a result of the erroneous program assumptions and defective implementation of the stabilization package, the economy was dealing with a transition from the shortageflation syndrome to stagflation, and even slumpflation. The stabilization policy of the end of 1989 and 1990-1991 was based on a somewhat primitive attempt to use the concept of the Washington Consensus, reduced mainly to the liberalization-privatization-hard financial policy triad, which did not fit the institutional and cultural realities of that time (Williamson 2005). As a result, open (price) inflation was even higher than in the previous period, while suppressed inflation (shortages) was replaced with a rapidly increasing mass unemployment (Kolodko 1992) (Fig. 1).

Interestingly, only China (Lin 2004; Kornai 2008; Hübner 2020) and Vietnam (Kolodko 1990; Kolodko et al. 1992; Popov 2006; Kornai - Qian 2009), thanks to their gradual reforms and prudent policy implemented, found their way out of the nightmare of the shortage economy, avoiding long-term recession and without provoking the outbreak of hyperinflation

Table 2. Recession and rate of inflation in Poland, 1990-1991 (\%)

\begin{tabular}{|l|c|c|c|}
\hline & 1990 & 1991 & $1992(1989=100)$ \\
\hline GDP official data & -11.6 & -7.0 & 82.2 \\
\hline Alternative estimation & -13.8 & -10.3 & 77.3 \\
\hline CPI & 585.8 & 70.3 & $1,167.9$ \\
\hline
\end{tabular}

Sources: Poland's Statistical Yearbook (GUS 2021b). Alternative estimations from Jakubowicz (2020).

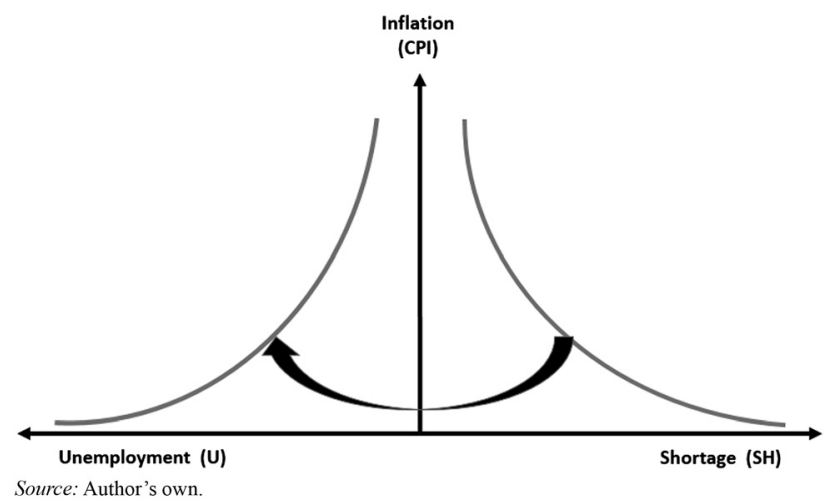

Fig. 1. From shortageflation to slumpflation 
(Guitián - Mundell 1996). Undoubtedly, the authoritarian regime was helpful (Kolodko 2020). In China, the successful elimination of shortages in a relatively short time was accompanied by economic growth, while price inflation associated with the release of prices remained low (Table 3).

The far-reaching effects of those shocks and subsequent macroeconomic reproduction processes are still clearly visible (Fig. 2), and their consequences - not only economic (Dabrowski 2020), but also geopolitical (Bell 2015; Economy 2018) - are wide-ranging.

The prevailing view today is that in the case of the Soviet and East European socialism, the state ownership of the means of production was the cause of soft budget constraints, and these, in turn, were the reason for inflation - more or less suppressed, or more or less open, depending on time and place, so on the systemic and political context. So it was, but have it inevitably to be that way? While Kornai claims that it did (Kornai 1992), Nuti thought that theoretically speaking, equilibrium prices clearing the market could be present in socialism without the need to introduce a regime of hard budget constraints (Nuti 2018a). According to his view that was not the case, it was not due to the nature of the system, but to the imperfection of the economic policy.

Whereas in China - as well as in Vietnam and in very underdeveloped Cambodia and Laos the policy makers overcame this problem. So, is Kornai not right, because equilibrium prices

Table 3. Economic growth and rate of inflation in China, 1990-1993 (\%)

\begin{tabular}{|l|c|c|c|c|}
\hline Year & 1990 & 1991 & 1992 & 1993 \\
\hline GDP & 3.8 & 9.2 & 14.2 & 14.0 \\
\hline CPI & 3.1 & 3.4 & 6.4 & 14.7 \\
\hline
\end{tabular}

Source: National Bureau of Statistics of China.

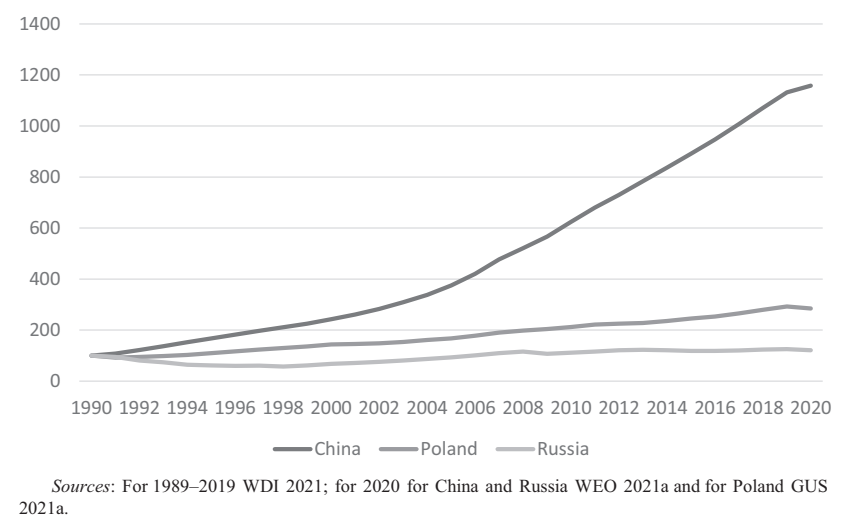

Fig. 2. GDP per capita in China, Poland and Russia, $1990=100$ (Purchasing Power Parity, in USD 2017) 
clearing the market are possible also in socialism? In places where it turns out well, does it involve hard or soft budget constraints? What is the result of the evolution of the Chinese economic system? Is it socialism with a balanced market, and more specifically, with the market characterised by overproduction and unemployment, as the flow of supply exceeds the flow of demand, or is it capitalism with still partly soft budget constraints? (Ellman 2021).

I say that neither one nor the other. The contemporary Chinese political system is qualitatively different from both state socialism with its inherent soft budget constraints, as well as from liberal capitalism, where hard constraints generally prevail (Huang 2017). This system can be referred to as Chinism (Kolodko 2018). It is a specific systemic hybrid, in which multiple forms of ownership of the means of production co-exist and which, at the intertwining of authoritarianism and meritocracy, creatively combines the power of the invisible hand of the market with the power of the visible hand of the state. So Kornai's thesis that eliminating shortages absolutely requires a transition to a capitalist market economy is not correct, but Nuti's supposition that it is possible to eliminate shortages in the state socialist economy still remains debatable. In practice, however, nobody has proved this, unless we accept as true the claim that the prevailing political system in China is socialism, but with "Chinese characteristics" (Hu 2019). ${ }^{2}$

In the countries of Central and Eastern Europe and the former Soviet republics, the initial phase of the post-socialist political transformation was accompanied by galloping inflation, and in some cases even hyperinflation, also because they did not manage to make use of the accumulated forced savings to boost the economy (Blejer - Skreb 2001; Popov 2014). Although it was postulated, this specific resource was not converted into a completely new genre in the post-socialist reality - into funds invested in securities. Then their surrogates could be issued in anticipation of the latter implementation - already after the stabilisation of the economy and the institutional basis of the capital market - of an extensive programme of privatization of state assets. Instead, the savings of people - not only those forced but also some voluntarily held reserves - were drained (Laski 1990; Poznanski 1996).

In Poland, following the so-called shock therapy, which led to a drastic decline in production, the real supply from domestic production fell noticeably. This was a consequence of both an obvious miscalculation of the stabilisation policy - especially the excessive interest rates on old loans, the repressive taxation of wage increases in state-owned enterprises, the excessive scale of devaluation of the zloty, and too rapid liberalisation of foreign trade - as well as the activities deliberately aimed at the state sector, which were motivated ideologically, surely not pragmatically (Kolodko - Nuti 1997). This forced the prices to rise even higher than they would inevitably rise as a result of price liberalization initiated on a large scale back in 1989. The decline in the total supply was prevented by the explosion of private imports financed by previously dormant multi-billion resources of convertible currencies that had been hoarded by households for years and in the last years of state socialism, when it was made possible by the gradual liberalization of the economy, including rigours of foreign trade settlement, also by businesses.

\footnotetext{
${ }^{2}$ For further readings on the interpretation of the recent Chinese economic developments, see Acta Oeconomica's recent Special Issue (2020, Vol. 70) including papers of Csaba, Dabrowski, Kolodko, Mihályi - Szelényi, Szunomár, Tanzi, Török - Nagy and Wojciech.
} 
As a result, in 1990, the inflation rate reached the staggering level of $586 \%$, and a year later still more than $70 \%$. The shock without therapy transformed the monetary overhang into an inflationary avalanche with its dire consequences both for the real economy as well as for the redistribution of wealth and income of people.

\section{ECONOMICS OF FLOWS AND ECONOMICS OF RESOURCES}

The American way of recovering from suppressed inflation 1.0 was commendable, the Chinese way of recovering from shortageflation 2.0 was good, if we limit ourselves to assessing purely economic aspects, while the Polish way of recovering from the same was very bad. Now, in a way the reappearance of inflation was difficult to predict, yet it had been imaginable. More precisely, suppressed inflation has reappeared; this is its 3.0 version. We should be surprised by the economists who cannot see this and are startled that "printing money" did not intensify the waves of inflation. Some of them point out the situation from the years 2008-2010, when the supply of money was also rapidly increased, and it did not result in accelerating inflation. This happened because the supply side effectively absorbed the additional mass of money, saving the real economy from depression after a brief, only a year-long recession, through positive adjustment processes; the gross world product declined by $1.7 \%$ only in 2009 , to increase again by $4.3 \%$ in the following year. With those unconventional reactions of the economic policy, the practice has been enriched with a new instrument of state interventionism, and the economic theory with a new term - quantitative easing (Blanchard et al. 2012). Central banks acquired substantial amounts of government bonds, issued to finance additional anti-crisis public spending, on the secondary market.

Yet, the current situation is different from that several years ago, as inflation is already higher than it can be read only from the analyses of price indices, both from the Consumer Price Indices as well as Producer Price Indices. What is worse, it can become even greater, if the current monetary and market situation is incorrectly interpreted, which may happen if the economics of flows is mistaken with the economics of resources. In the crisis we are going through now, a significant part of the flow in the form of an inflation gap, meaning a surplus of effective demand over the flow of aggregate supply, has transformed into savings forced by the market situation, that is the inflationary overhang.

As the pandemic begins to subside and the situation begins to improve, part of this resource will turn back into the flow. Given that in practice, inflation-free offset of demand growth by a hypothetical conversion of the entire resource is not possible, the smaller the converted part, the better, as the milder the inflationary impulse will be. The economic policy must bear this in mind. There is little that can be achieved here simply by raising interest rates, but there is no escape from resorting to this monetary policy instrument either.

After all, attempts to counter inflation using this method must be approached very prudently this time, because, in the economic sphere, the coronavirus pandemic has created not only a considerable inflationary potential but also serious unemployment. If central banks decide to raise interest rates too rapidly in the wake of accelerating price inflation, it may - but does not have to - block price increases, but at the expense of slower recovery of old jobs, lost as a result of the crisis, and the creation of new ones. In the short term, an alternative clearly manifests itself: inflation versus unemployment. Until now, after the unpleasant experience of high inflation of the 1970s, a monetarist doctrine has prevailed together with a resulting practice that 
required that inflation was counteracted even at the expense of weakening economic dynamics and increasing unemployment.

It is different now and it is no longer possible to treat high unemployment and the accompanying growth of poverty and various pathologies, from social exclusion to crime, as inevitable side effects of the battle against inflation. There is already a change in the approach of some central banks visible, which emphasises the imperative of tackling unemployment by stimulating the economy in parallel with mitigating inflation. According to the new rules of monetary policy adopted last year, the US Federal Reserve has moved to the so-called average inflation target as a reference point of its policy. The Fed now emphasizes maximizing employment also as an important objective, suggesting that inflation may temporarily exceed the previously set target of $2 \%$, as long as it helps more people find employment. A similar departure from the previous practice has been announced by the Bank of Japan, and it was introduced even earlier by the Reserve Bank of New Zealand, perhaps the most orthodox central bank in the world in this respect after 1980. The monetary policy should follow such road in the difficult mission of simultaneously overcoming the effects of the pandemic crisis in the sphere of production and employment, on the one hand, and the rational curbing of inflation, on the other. The answer to the question of what is "rational" is contextual and depends on the specific situation of the country.

Central banks can be expected to exercise restraint in raising interest rates also because keeping nominal interest rates below the rate of inflation, and thus, persisting with negative real interest rates, will depreciate household and corporate financial reserves. Of course, for political reasons, such behaviour will be justified as a concern for the stimulation of investments and production as well as employment. Either way, a relatively long period of negative real interest rates is to be expected, far longer than was the case with the 2008-2010 crisis and its aftermath.

Negative real interest rates on a significant portion of bank deposits should also be seen as a kind of substitute for raising taxes. Their higher rates imposed on current income would drain part of this flow, which could encourage the affected economic entities to reach to their accumulated resources, meaning savings, including those of a forced nature, on a much larger scale. To some extent, it is not only the accumulation of funds for major investments and social programmes, as announced by President Joe Biden, but also this is the intention of the White House's policy, aiming to seriously increase the fiscal burdens, especially on business and the wealthier groups of people. In other words, in a particular situation, higher taxes may contribute to a lower price inflation. This is a much more complicated issue than a simple either-or alternative, as the policy must also take into account other objectives, especially income redistribution, employment and unemployment, production activity and its profitability, and investments.

The circumstances are particularly interesting, as more information on the issue of possible changes in future inflation can be provided by behavioural economics (Thaler 2016), rather than by monetary economics, especially the knowledge of psychological factors affecting human expectations and the rationale of decisions on how to use the financial resources held (Thaler Sunstein 2009). It may happen that a rapid increase in interest rates - even once by 100 and more basis points - will not stop the growth of the inflation rate if the nature of expectations will encourage the economic entities to spend the money. Moreover, in the initial period of recovery from the pandemic crisis, real negative interest rates can still be expected, and it discourages saving. 
In the year of the pandemic cataclysm, gross world product fell by $3.3 \%$, with the magnitude of changes in the level of production varying widely; for the economies of major importance to the global average, it ranged from a decline by $8.0 \%$ in India to an increase by $2.3 \%$ in China. Among the rich countries, the rate of decline in GDP in 2020 fluctuated between $3.5 \%$ in the US and $11 \%$ in Spain. The EIU estimates that globally retail sales in total fell by around 2\%, while online sales rocketed up by as much as $30 \%$. It was online trading that has saved us from an even greater scale of increase in forced savings. We could not spend money in shopping malls, we could buy online; we could not go to the cinema, we could subscribe to Netflix; we could not search for interesting books through the shelves of bookstores, we downloaded e-books onto Kindle; we could not go to a restaurant, we ordered home delivery of dinner. The structural changes that have taken place in this field as a result of the pandemic shock will largely prove to be permanent (Kolodko 2021).

It is estimated that in 21 countries of highly developed capitalism excessive savings in 2020 amounted to over 3 trillion US dollars (Economist 2021a). They are excessive in the sense that they are so much greater than they would be if the pre-pandemic trends would have continued (Fig. 3).

Despite this, classical price inflation was low, ranging in 2020 in the group of the major Western economies, the G7, from a negligible $0.4 \%$ in Italy to $1.4 \%$ in the US. In Japan, prices fell by $0.6 \%$. The average for the member countries of the OECD was $1.5 \%$. For 2021, it is forecast (this time these are the EIU's estimates) to be still low: from $0.2 \%$ in Japan and $1.1 \%$ in France to $1.9 \%$ in the USA, and $2.1 \%$ in Canada. The optimism of these forecasts is striking, but I will not be surprised if inflation turns out to be higher.

This optimism is also reflected in the exceptionally strong growth in global world product assumed by the IMF in spring 2021 - by as much as 6\% (and by $4.4 \%$ in 2022). It is thus assumed - again, very optimistically, but is it realistic? - that after a one-year recession, the economy will more than recover (Table 4).

If things turn out this way, it will mean that the first channel is decisive for absorbing excess savings, that it is the additional demand generated by the conversion of a resource into a flow of effective demand that fuels the economy, increasing production and employment by the better use of production capacities. This is the best possible scenario, but will it come true?

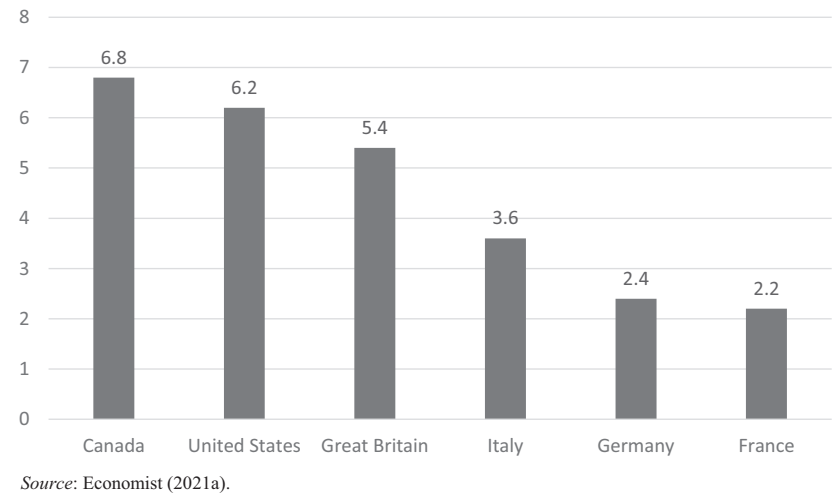

Fig. 3. Excessive savings in large, advanced economies (in \% of GDP) 
Table 4. GDP contraction and growth forecast in selected countries, 2020-2022 (\%)

\begin{tabular}{|l|c|c|c|}
\hline \multirow{2}{*}{ Country } & \multicolumn{3}{|c|}{ Year } \\
\cline { 2 - 4 } & $\mathbf{2 0 2 0}$ & $\mathbf{2 0 2 1}$ & $\mathbf{2 0 2 2}$ \\
\hline Canada & -5.4 & 5.0 & 4.7 \\
\hline China & 2.3 & 8.4 & 5.6 \\
\hline Euro Area & -6.6 & 4.4 & 3.8 \\
\hline France & -8.2 & 5.8 & 4.2 \\
\hline Germany & -4.9 & 3.6 & 3.4 \\
\hline Great Britain & -9.9 & 5.3 & 5.1 \\
\hline India & -8.0 & 12.5 & 6.9 \\
\hline Japan & -4.8 & 3.3 & 2.5 \\
\hline United States & -3.5 & 6.4 & 3.5 \\
\hline
\end{tabular}

Source: WEO (2021b).

In Poland, the financial resources of both businesses and people have also increased considerably. In the first case, despite the drop in GDP by $2.8 \%$ in 2020 , they increased by around PLN 70 billion, that is by some 25 billion more than the year before, according to the National Bank of Poland. This amount - more than 1\% of GDP - is, in simple terms, their forced savings. What is more, of the amount equivalent to about PLN 70 billion (about 3\% of GDP) held by the business sector in banks in the foreign currency accounts, some part - perhaps more than half - is also forced by market realities. Such significant unwanted savings, stemming from the lack of sufficiently attractive production and investment spending opportunities in the eyes of business due to the periodic freezing of the economy and the downturn, suggest that once unfrozen, the spending pressure may cause a relatively high level of price inflation in the production sphere. Over time, the resulting additional increase in production costs will be passed on to consumer prices.

In the second case, in relation to households, a great of the special protective measures transferred by the government in the successive phases of the anti-crisis policy also turned into forced savings. According to the National Bank of Poland (NBP 2021), transferable overnight deposits of households grew despite their negative real interest rate of $-3.4 \%$ and amounted to about PLN 827 billion at the end of Q1 2021, that is more than PLN 180 billion, as much as 30\% more than a year earlier when COVID arrived and the economy freezing began. For comparison, in 2019, the year preceding the pandemic, analogous deposits increased by PLN 80.4 billion, i.e., by $15.4 \%$, while during just the first three months of 2021 they grew by 42.2 billion. In other words, during the pandemic, these funds grow roughly twice as fast as in the period preceding it (Fig. 4). And we should remember that the amount in question is only the money held in banks, but there is also quite a lot held on the stock market, in various investment funds, insurance policies, and in cash. Some of these funds are the modern equivalent of the inflationary overhang. 


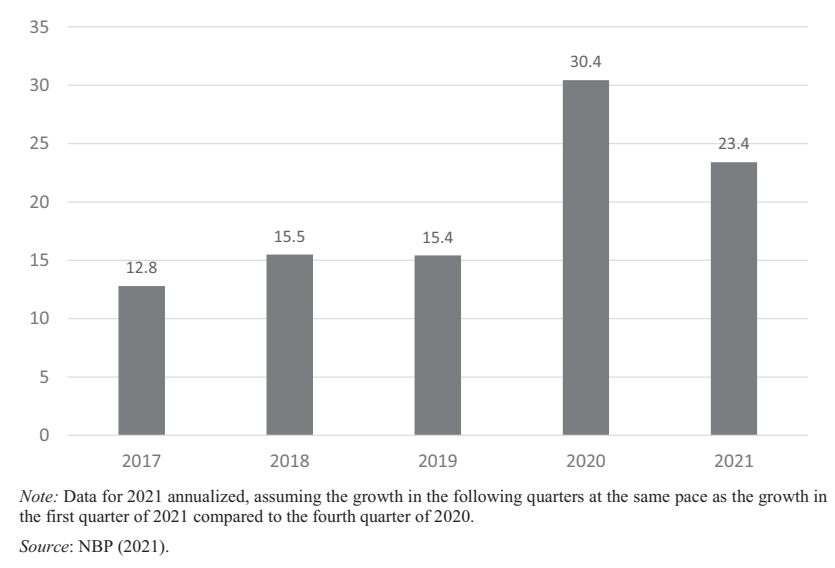

Fig. 4. Increase in current deposits and other liabilities of banks to households in Poland, 2017-2021 (\%)

Thus, when comprehensively estimating the extent of shortageflation 3.0, current inflation taking into account both open and suppressed inflation -its rate oscillates around 5\%, which is one and a half times higher than the official rate announced by the GUS. In other words, this is how high - and perhaps even higher, while it is a greatly fluctuating number given the emotional and not always rational decisions of people regarding the management of their own financial resources - price inflation could be if, in the face of the anti-crisis "printing" of money, the significantly increased demand was not suppressed and compulsorily deferred in any way.

Any such estimate must be based on partly arbitrary assumptions, since it is impossible to accurately assess the size of the second component of the shortageflation rate, i.e., the hypothetical additional increase in the price level in the face of full liberalisation of production and distribution. Such an attempt was once made for the 2.0 case. This requires first to quantify the savings forced by the shortages and to express them in percentages so that this rate can be added up with the rate of price inflation.

The estimate of the rate of shortage deducts the sum of the stock of savings held for retirement and of liquid asset balances held for transaction and precautionary purposes from the population's total liquid asset balances:

$$
\mathrm{rSH}=\frac{\mathrm{R}_{\mathrm{m}}-\left(\mathrm{S}_{\mathrm{v}}+\mathrm{T}_{\mathrm{r}}\right)}{\mathrm{Y}}
$$

where

$\mathrm{rSH}=$ the rate of shortage, expressed as a fraction of GNP, (Y),

$\mathrm{R}_{\mathrm{m}}=$ population's total liquid asset balances,

$\mathrm{S}_{\mathrm{v}}=$ financial assets other than money and savings accounts, assumed to be held largely for retirement,

$\mathrm{T}_{\mathrm{r}}=$ money and savings account balances desired for transaction, and precautionary (and speculative) purposes. 
Table 5. Average rate of shortageflation in selected socialist countries, 1977-1984 (\%)

\begin{tabular}{|l|c|}
\hline Country & Shortageflation rate \\
\hline Bulgaria & 6.9 \\
\hline Czechoslovakia & 5.1 \\
\hline East Germany & 3.1 \\
\hline Hungary & 8.9 \\
\hline Poland & 29.4 \\
\hline Romania & 8.3 \\
\hline Soviet Union & 4.6 \\
\hline
\end{tabular}

Source: Kolodko - MacMahon (1987).

After adding price and suppressed inflation rates, the average price and repressed inflation rates, shortageflation, for the European socialist countries over the eight years of 1977-1984, ranged from a modest 3\% in East Germany to a significant 30\% in Poland (Table 5).

Although under no circumstances should it be underestimated, the phenomenon of current shortageflation is far less inconvenient to people and less damaging to the economy than its earlier versions. Back then the suppression of inflation was accompanied by pathologies in market relations: queues, rationing, forced substitution, the black market, barter transactions, corruption of suppliers and sellers, and selling under the counter. Formerly one could bribe a seller of a washing machine that was supposedly out of stock but was found in the back of the store; nowadays, it is impossible to get the desired air ticket if the plane is there but does not fly because of the lockdown. In the past, the authorities organised a narrow network of special wellstocked points of sale for the privileged few, nowadays, you cannot get tickets for an opera première using your informal connections, if the theatres are closed to everyone due to the lockdown. Now these pathologies, with all their important differences and specific nuances, manifest themselves to a negligible extent, mainly due to the short duration of the phenomenon and the specificity of supply constraints.

Of course, in the wider world today there are also exceptions, like the extreme case of totalitarian North Korea, where symptoms of all three types of shortageflation - 1.0, 2.0, and 3.0 - converge, or the anachronistic state socialism in Cuba, where the 2.0 variant couples with 3.0. Such contemporary comparisons in space, just like looking for analogies in time, not only show the similarities of all three types of inflation suppression in the form of the accumulation of forced savings by producers and consumers but also highlight their differentia specifica.

Shortageflation 1.0 was caused by administrative orders and prohibitions breaking the rules of the free market economy. There were enough raw materials, capital and labour to ensure a sufficient supply of consumer goods under normal conditions, but by political decisions, these were periodically, for the abnormal times of war, transferred to fulfil other purposes. The shortageflation syndrome inherent to the economy of the state socialism, variant 2.0, was, in turn, a systemic feature. The economy, by its very systemic nature, when faced with the 
procedure of politically motivated price controls, was unable to supply enough goods and services to balance the flow of demand it stimulated. It was supposed to be cheap so that things would be there for everyone, over time it was relatively cheap, but not enough for many.

Hence, the phenomenon of 3.0 version is different from the previous two. By the very nature of the capitalist economy, production capacities are excessive from the point of view of an insufficient effective demand, but the additional constraints on their use imposed by the unorthodox anti-crisis policy instruments in pandemic conditions cause that more could be produced, sold, bought and consumed at the same time, but it is prohibited to do so. Thus, similarly as in variants 1.0 and 2.0, there are forced savings, but in addition - and this is a major difference - there are reserves of production capacities. In the 1.0 variant, it was negligible; the war economy was in full swing. In the 2.0 variant, they were virtually non-existent, and if they existed somewhere, it was because of the structural imbalance of the economy. A part of the factory was at a standstill because it had just been affected by shortages of the components required to maintain the continuity of production while at the same time another company was hoarding such components and had excess inventory.

\section{CONCLUSIONS}

The situation is special because the nature of the crisis caused by the COVID coronavirus pandemic is unprecedented. This time, the turbulences in the reproduction process are taking place both on the supply side - mainly in the form of broken supply chains, whose transnational role has increased enormously in the age of globalisation, and temporary bans on production and especially on services - as well as on the demand side. The orthodox economic thought often fails to provide suggestions on how to minimise the costs of micro- and macroeconomic adjustments to specific challenges, which overlap with other ills, especially those related to the protectionist practices that spread under the new nationalism and populism. Economic, social, and political realities, different from what we know from the past, confront us with the imperative to seek innovative theoretical interpretations. The more accurate they are and the earlier they appear; the more effective corporate management and pragmatic economic policies can draw on them.

We know that, given the situation resulting from the pandemic, economies will recover from the syndrome of shortageflation 3.0 through five channels:

$$
\sum_{\mathrm{FS}}=\mathrm{d}_{\Psi}+\mathrm{d}_{\mathrm{IM}}+\mathrm{d}_{\mathrm{vS}}+\mathrm{d}_{\mathrm{Ap}}+\mathrm{d}_{\mathrm{CPI}}
$$

where

$\Sigma_{\mathrm{FS}}$ - forced savings arising under pandemic perturbations,

$\mathrm{d}_{\Psi}$ - an additional flow of demand stimulating the production and supply growth,

$\mathrm{d}_{\mathrm{IM}}$ - financing additional imports from reserves previously compulsorily held,

$\mathrm{d}_{\mathrm{VS}}$ - an increase in voluntary savings as a result of a change in the preferences of the holders of previously compulsorily unspent funds,

$\mathrm{d}_{\mathrm{AP}}$ - financial resources absorbed by an additional increase in the prices of raw materials and assets,

$\mathrm{d}_{\mathrm{CPI}}$ - funds drained by an additional inflationary price increase. 
Now, ex-ante, we do not know the proportions of these five components of the equation. We do not know to what extent and at what pace, in the post-pandemic economy, the stocks of compulsory savings will be transformed into a flow of additional effective demand, and this along with the scale of production growth in subsequent periods - will be crucial for the intensification of inflationary processes, those already entirely open.

A significant part of the compulsory savings has arisen as a result of the drastic reduction in the possibility of enjoying services, especially travel, tourism, leisure and entertainment. Countries where the hospitality sector accounts for a relatively large part of employment and national income, such as Mexico, Kenya, Italy and Thailand, are particularly hard hit. Money unspent in 2020 on airline tickets, hotels, restaurants, concerts, museums and galleries has already become voluntary savings to a considerable but unknown extent. Still, as soon as these service sectors gain momentum again, after an initial period of discounts to encourage spending, prices will rocket. Airline tickets to exotic countries will be more expensive, we will pay more for the next Beyoncé concert, the owner of our favourite restaurant will make it up on us, a masseur will charge us appropriately, a plumber will take more money, shopping in a bookstore will cost us more.

It can be assumed that New Zealand and Australia in the Spring of 2021 were closest to the state that can be described with some approximation as a post-pandemic reality. It is worth noting that in New Zealand restaurants, cafés, shopping centres and amusement parks were visited more frequently than before the pandemic, and in Australia, in the first two months of 2021, the number of restaurant visitors was 65\% higher than a year earlier (Economist 2021b). In both cases, such a large increase in the effective demand intensifies inflationary pressures and can result in higher prices.

We also do not know how much demand will go abroad and, by stimulating the economy elsewhere, worsen the domestic balance of payments. This is already evident in the case of the US, where a sizeable portion of the extraordinary budget spending, which sustains the population's consumption levels and intentionally supports US businesses, finances imports, especially from China (Hessler 2021), on which the Americans otherwise impose economic sanctions, how ineffectively. The globalised economy is a system of interconnected vessels, and it is worth to understand how its mechanisms work (Wolf 2004; Galbraith 2014). Nowadays, it is necessary to act very prudently so that, with all the obvious differences, there would be as many similarities as possible to the American way of recovering from the suppressed inflation 1.0, and as few as possible to the Polish case of 2.0.

What we do know is that an important part - although we do not know how large - of the additional flow of money that has flowed into the market and got temporarily immobilised as an inflationary overhang is activated in the market of assets. Their prices are already going up and will continue to do so for some time. This additionally reinforces inflation expectations and stimulates speculation. The beginnings of a speculative bubble can already be noticed in some segments of the asset market, especially in the housing market. Inevitably, the time will come when it will burst causing further crisis phenomena. This can be countered by the targeted taxation of speculative transactions to temper their scope. The prices of other assets, above all of many raw materials, especially petrochemicals and metals, shares on some stock exchanges, and cryptocurrencies will continue to behave chaotically, although with a tendency towards strong increases. There is no doubt that the relative excess of money in circulation is the grist for the mill of the nascent cryptocurrency market, where the drops will be as spectacular as the rises. 
Syndrome 3.0 is, after all, qualitatively different from the previous cases of 1.0 and 2.0. It is, therefore, necessary to tone down the inflationary expectations; also, in the professional public narrative. Above all, entrepreneurs must be encouraged to invest in production by various means. This can be facilitated by increasing complementary public investments, which, in the case of the US, the administration of President Joe Biden intends to do on a large scale, running into trillions of dollars. The European Union plans to spend by the end of 2026 EUR 750 billion from the common funds as part of the Recovery and Resilience Plans. These funds, in the form of loans and grants, in specified proportions, are planned to go to 27 Member States, which will distribute them under the National Recovery Plans. This public spending will undoubtedly attract private investments which, if well-targeted by the market, will create new production capacities absorbing the growing flow of demand.

The population, on the other hand, needs to be continually convinced about the sense of sustainable saving. If we have involuntarily saved some money under a kind of temporary pressure, we should not run with them to the unblocked market as soon as better times come because they will - but convert it into voluntary savings through sheer willpower: for better holidays, for home improvements, for continuous education, for additional financing of our future standard of living, for topping up our pensions. Just in case.

\section{REFERENCES}

Adirim, I. G. (1983): Stagflation in the U.S.S.R. Falls Church, VA: Delphic Associates.

Bell, D. A. (2015): The China Model: Political Meritocracy and the Limits of Democracy. Princeton, New Jersey: Princeton University Press.

Blanchard, O. J. - Romer, D. - Spence, A. M. - Stiglitz, J. E. (eds) (2012): In the Wake of Crisis: Leading Economists Reassess Economic Policy. Cambridge Mass. - London: The MIT Press.

Blejer, M. I. - Skreb, M. (eds) (2001): Transition: The First Decade. Cambridge, Mass. - London: The MIT Press.

Blinder, A. S. (1979): Economic Policy and the Great Stagflation. New York: Academic Press.

Charlesworth, H. K. (2003): The Economics of Repressed Inflation. Abigdon, Oxon: Routledge.

Csaba, L. (2020): China at the Crossroads. Acta Oeconomica, 70(S): 5-14.

Dabrowski, M. (2020): Transition to a Market Economy: A Retrospective Comparison of China with Countries of the Former Soviet Block. Acta Oeconomica, 70(S): 15-45.

Economist (2021a): The World's Consumers Are Sitting on Piles of Cash. Will They Spend it? The Economist, March 9. (https://www.economist.com/finance-and-economics/2021/03/09/the-worldsconsumers-are-sitting-on-piles-of-cash-will-they-spend-it).

Economist (2021b): The Fed Should Explain How It Will Respond to Rising Inflation. The Economist, April

17. (https://www.economist.com/leaders/2021/04/15/the-fed-should-explain-how-it-will-respond-torising-inflation).

Economy, E. C. (2018): The Third World Revolution: Xi Jinping and the New Chinese State. New York: Oxford University Press.

Ellman, M. (2021): János Kornai: Economics, Methodology and Policy. Cambridge Journal of Economics, 45(2): 371-390. 
Estrin, S. - Uvalic, M. (2021): The Life and Works of Domenico Mario Nuti, 1937-2020: An Appreciation. Acta Oeconomica, 71(2): 181-194.

Galbraith, J. K. (2014): The End of Normal: The Great Crisis and the Future of Growth. New York: Simon and Schuster.

Guitián, M. - Mundell, R. A. (eds) (1996): Inflation and Growth in China. Proceedings of a Conference held in Beijing, China, May 10-12, 1995. IMF.

GUS (2021a): Produkt krajowy brutto w 2020 roku - szacunek wstępny. Główny Urząd Statystyczny, Warszawa (Gross Domestic Product in 2020 - preliminary estimate. Central Statistical Office, Warsaw). (https://stat.gov.pl/obszary-tematyczne/rachunki-narodowe/roczne-rachunki-narodowe/produktkrajowy-brutto-w-2020-roku-szacunek-wstepny,2,10.html).

GUS (2021b): Roczne wskaźniki cen towarów i usług konsumpcyjnych od 1950 roku, Główny Urzạd Statystyczny, Warszawa (Annual price indices of consumer goods and services since 1950. Central Statistical Office, Warsaw). (https://stat.gov.pl/obszary-tematyczne/ceny-handel/wskazniki-cen/ wskazniki-cen-towarow-i-uslug-konsumpcyjnych-pot-inflacja-/roczne-wskazniki-cen-towarow-iuslug-konsumpcyjnych/).

Harvey, D. (2005): A Brief History of Neoliberalism. Oxford - New York: Oxford University Press.

Hicks, J. R. (1947): The Empty Economy. Lloyds Bank Review, New Series, No. 5, London.

Hessler, P. (2021): Manufacturing Diplomacy. The New Yorker, March 15: 50-59. (https://archives. newyorker.com/newyorker/2021-03-15/flipbook/54/).

Historical UK Inflation (2021): Historical UK Inflation Rates and Calculator. (https://inflation.iamkate.com/).

Howard, D. H. (1976): A Note on Hidden Inflation in the Soviet Union. Soviet Studies, 28: 599-608.

Hu, B. (2019): The Source of China's Confidence: How to Understand Socialism with Chinese Characteristics. Beijing: Foreign Languages Press.

Huang, Y. (2017): Cracking the China Conundrum: Why Conventional Economic Wisdom Is Wrong. New York: Oxford University Press.

Hübner, W. (2020): China - Cooperation and Rivalry in Today's Interdependent World: Will Pandemic Change the Trends? Acta Oeconomica, 70(S): 47-69.

Jakubowicz, A. (2020): Spadek i wzrost gospodarczy w okresie transformacji polskiej gospodarki (Economic decline and growth in the period of transformation of the Polish economy). Biuletyn Polskiego Towarzystwa Ekonomicznego, 1(88): 49-57.

Kolodko, G. W. (1984): Inflationary Alternative. Polish News Bulletin of the British and American Embassies, Economic Review, No. 18-84: 14-22.

Kolodko, G. W. (1986): The Repressed Inflation and Inflationary Overhang under Socialism. Working Paper, No. 1228, Bureau of Economic and Business Research, University of Illinois, Urbana-Champaign.

Kolodko, G. W. (1990): Hyperinflation and Stabilization in Postsocialist Economies (The Case of Poland, Vietnam and Yugoslavia). Working Paper, No. 16, Institute of Finance, Warsaw. (http://www.tiger.edu. pl/kolodko/working/if/IF_working_papers_nr16.pdf).

Kolodko, G. W. (1991): Polish Hyperinflation and Stabilization 1989-1990. Economic Journal on Eastern Europe and the Soviet Union, 1: 9-36.

Kolodko, G. W. (1992): Economics of Transition: From Shortageflation to Stagflation. The Case of Poland. In: Clesse, A. - Tökés, R. (eds): Preventing a New East-West Divide: The Economic and Social Imperatives of the Future Europe. Baden-Baden: Nomos Verlagsgesellschaft, pp. 172-181.

Kolodko, G. W. (2000): From Shock to Therapy: The Political Economy of Postsocialist Transformation. Oxford - New York: Oxford University Press. 
Kolodko, G. W. (2018): Socialism, Capitalism, or Chinism? Communist and Post-Communist Studies, 51(4): 285-298.

Kolodko, G. W. (2020): China and the Future of Globalization: The Political Economy of China's Rise. London - New York: Bloomsbury I.B. Tauris.

Kolodko, G. W. (2020): The Great Chinese Transformation: From the Third to the First World. Acta Oeconomica, 70(S): 71-83.

Kolodko, G. W. (2021): The Quest for Development Success: Bridging Theoretical Reasoning with Economic Practice. Lanham - Boulder - New York - London: Rowman \& Littlefield Lexington Books.

Kolodko, G. W. - McMahon, W. (1987): Stagflation and Shortageflation: A Comparative Approach. Kyklos, 40(2): 176-197.

Kolodko, G. W. - Gotz-Kozierkiewicz, D. - Skrzeszewska-Paczek, E. (1992): Hyperinflation and Stabilization in Postsocialist Economies. Boston - Dordrecht - London: Kluwer Academic Publishers.

Kolodko, G. W. - Nuti, D. M. (1997): The Polish Alternative: Old Myths, Hard Facts and New Strategies in the Successful Transformation of the Polish Economy. Research for Action, 33, Helsinki: The United Nations University World Institute for Development Economics Research (WIDER). (https://www. wider.unu.edu/sites/default/files/RFA33.pdf).

Kornai, J. (1980): Economics of Shortage. Amsterdam: North-Holland.

Kornai, J. (1982): Growth, Shortage and Efficiency: A Macrodynamic Model of Socialist Economy. Oxford: Basil Blackwell.

Kornai, J. (1986): The Soft Budget Constraints. Kyklos, 39(1): 3-30.

Kornai, J. (1992): The Socialist System: The Political Economy of Communism. New Jersey: Princeton University Press.

Kornai, J. - Qian, Y. (2009): Market and Socialism: in the Light of the Experiences of China and Vietnam. Houndmills, Basingstoke, Hampshire - New York: Palgrave Macmillan.

Laski, K. (1990): The Stabilization Plan for Poland. Wirtschaftspolitische Blätter, 5: 444-458.

Lin, J. Y. (2004): Lessons of China's Transition from a Planned to a Market Economy. Distinguished Lectures Series, No. 16, Leon Kozminski Academy of Entrepreneurship and Management, Warsaw. (http://www.tiger.edu.pl/publikacje/dist/lin.pdf).

Lopez, J. A. - Michener, K. J. (2018): Uncertainty and Hyperinflation: European Inflation Dynamics after World War I. Working Paper, No. 6, Federal Reserve Bank of San Francisco. (https://www.frbsf.org/ economic-research/files/wp2018-06.pdf).

Measuring Worth Foundation (2021): What Was the U.K. GDP Then? The Historic Series. MeasuringWorth.com (https://www.measuringworth.com/datasets/ukgdpir/result.php).

Mihályi, P. - Szelenyi, I. (2020): China, Eastern Europe and Russia Compared. Acta Oeconomica, 70(S): 8593.

Mundell, R. A. (1995): Great Contractions in Transition Economies. Paper prepared for the First Dubrovnik Conference on Transition Economies, June.

Mundell, R. A. (1996): Inflation and Growth in the Transition Economies. In: Guitian, M. - Mundell, R. A. (eds): Inflation and Growth in China. Washington, DC: IMF, pp. 100-106.

NBP (2021): Statystyka i sprawozdawczość. Należności i zobowiązania monetarnych instytucji finansowych $i$ banków. National Bank of Poland, Warsaw. (https://www.nbp.pl/home.aspx?f=/statystyka/pieniezna i_bankowa/nal_zobow.html).

Nuti, D. M. (1986): Hidden and Repressed Inflation in Soviet-Type Economies: Definitions, Measurements and Stabilization. Contributions to Political Economy, 5: 37-82. 
Nuti, D. M. (1990): Crisis, Reform, and Stabilization in Central Eastern Europe: Prospects and Western Response. In: Biagini, A. (ed.): La Grande Europa, la Nuova Europa: Opportunità e Rischi. Siena. Monte dei Paschi di Siena.

Nuti, D. M. (2018a): Kornai: Shortage versus Surplus Economies. Acta Oeconomica, 68(1): 85-98.

Nuti, D. M. (2018b): The Rise and Fall of Socialism. Dialogue of Civilizations Research Institute, Berlin. (https://doc-research.org/2018/05/rise_and_fall_of_socialism/).

Podkaminer, L. (1992): Macroeconomic Policy for the Transitional Reforms in the Centrally-Planned Economies. In: Kovács, J. M. - Tardos, M. (eds): Reform and Transformation in Eastern Europe: SovietType Economics on the Threshold of Change. London - New York: Routledge, pp. 263-282.

Popov, V. (2006): Shock Therapy versus Gradualism Reconsidered: Lessons from Transition Economies After 15 Years of Reforms. TIGER Working Paper Series, No. 82, Leon Kozminski Academy of Entrepreneurship and Management, Warsaw. (http://www.tiger.edu.pl/publikacje/TWPNo82.pdf).

Popov, V. (2014): Mixed Fortunes: An Economic History of China, Russia, and the West. New York: Oxford University Press.

Portes, R. (1977): The Control of Inflation: Lessons from East European Experience. Economica, 44(174): 109-129.

Poznanski, K. (1996): Poland's Protracted Transition: Institutional Change and Economic Growth. Cambridge: Cambridge University Press.

Reinsdorf, M. B. (2020): COVID-19 and the CPI: Is Inflation Underestimated? Working Paper, WP/20/224, IMF (https://www.imf.org/en/Publications/WP/Issues/2020/11/05/COVID-19-and-the-CPI-IsInflation-Underestimated-49856).

Rosati, D. K. (1991): The Polish Road to Capitalism: A Critical Appraisal of the Balcerowicz Plan. Thames Papers in Political Economy, School of Social Sciences, Thames Polytechnic, London.

Steiner, J. E. (1982): Disguised Inflation in Soviet Industry. Journal of Comparative Economics, 3: 278-287.

Szunomár, Á. (2020): The Digital Great Leap Forward. Mapping China's 21st Century Attempt to Create a New Growth Model. Acta Oeconomica, 70(S): 95-115.

Tanzi, V. (2020): China's Economy: From Past to Future. Acta Oeconomica, 70(S): 117-126.

Thaler, R. H. (2016): Misbehaving: The Making of Behavioral Economics. New York: W.W. Norton \& Company.

Thaler, R. H. - Sunstein, C. R. (2009): Nudge: Improving Decisions about Health, Wealth, and Happiness. London: Penguin Books.

Török, Á. - Nagy, M. (2020): China: A Candidate for Winner in the International Game of Higher Education? Acta Oeconomica, 70(S): 127-152.

US Inflation (2021): US Inflation Rate by Year from 1929 to 2023. The Balance, (https://www.thebalance. com/u-s-inflation-rate-history-by-year-and-forecast-3306093).

US GDP (2021): US GDP by Year Compared to Recessions and Events. The Balance, (https://www. thebalance.com/us-gdp-by-year-3305543).

WDI (2021): World Development Indicators. The World Bank, Washington, D.C. (https://databank. worldbank.org/source/world-development-indicators\#).

WEO (2021a): World Economic Outlook Update. IMF, January (https://www.imf.org/en/Publications/ WEO/Issues/2021/01/26/2021-world-economic-outlook-update).

WEO (2021b): World Economic Outlook: Managing Divergent Recoveries. IMF, April (https://www.imf.org/ en/Publications/WEO/Issues/2021/03/23/world-economic-outlook-april-2021).

Wiles, P. (1982): Soviet Consumption and Investment Prices, and the Meaningfulness of Real Investment. Soviet Studies, 34: 289-295. 
Williamson, J. (2005): Differing Interpretations of the Washington Consensus. Distinguished Lectures Series, No. 17, Leon Kozminski Academy of Entrepreneurship and Management, Warsaw (http://www. tiger.edu.pl/publikacje/dist/williamson.pdf).

Winiecki, J. (1991): Costs of Transition that are not Costs: On Non-Welfare-Reducing Output Fall. Rivista di Politica Economica, VI: 85-94.

Wojciech, H. (2020): China - Cooperation and Rivalry in Today's Interdependent World: Will Pandemic Change the Trends? Acta Oeconomica, 70(S): 47-69.

Wolf, M. (2004): Why Globalization Works. New Haven and London: Yale University Press. 